ББК 63.3(5Каз)

УДК 94(574/575)

\title{
Система государственного налогообложения городского недвижимого имущества в центральноазиатских окраинах Российской империи (конец XIX — начало XX в.)
}

\author{
Ю.А. Льсенко, А.С. Жанбосинова ${ }^{2}$ \\ ${ }^{1}$ Алтайский государственный университет (Барнаул, Россия) \\ ${ }^{2}$ Восточно-Казахстанский государственный университет им. С. Аманжолова \\ (Усть-Каменогорск, Казахстан)

\section{The System of State Taxation of Urban Real Estate in the Central Asian Outskirts of the Russian Empire in the Late $19^{\text {th }}-$ Early $20^{\text {th }}$ Centuries}

\author{
Yu.A. Lysenko', A.S. Zhanbosinova ${ }^{2}$ \\ ${ }^{1}$ Altai State University (Barnaul, Russia) \\ ${ }^{2}$ Sarsen Amanzholov East Kazakhstan State University (Ust-Kamenogorsk, \\ Kazakhstan)
}

На основе документов делопроизводства органов власти Степного и Туркестанского генерал-губернаторств, а также статистических данных анализируется процесс формирования региональной модели государственного налогообложения на недвижимое городское имущество. Отмечается, что господство традиционных экономических отношений в центральноазиатских окраинах, незначительное присутствие в региональной экономике рыночного сектора и соответствующей ему городской инфраструктуры исключали возможность проведения здесь земской реформы и создания органов местного самоуправления - земств. Этот факт определил особенности формирования системы земских повинностей, в том числе налогообложения на городское недвижимое имущество. Данный налог начал вводиться в центральноазиатских окраинах гораздо позднее, чем в целом по империи - в конце XIX в., его распределение и контроль были возложены на областные и уездные правления. В условиях неравномерного роста численности городов и городских поселений в областях Степного края и Туркестана в пореформенный период введение государственного налога на городское недвижимое имущество происходило поэтапно. Так, в Степном крае городское население стало выплачивать данный налог с момента введения Степного положения в 1891 г., в Туркестане - только с 1905 г. Следует отметить, что суммы, поступаемые от сбора налога на недвижимое имущество, были незначительными и не могли в полном финансовом объеме обеспечить инфраструктурное и социальное развитие городов и городских поселений центральноазиатских окраин Российской империи.
The article analyzes the process of formation of the regional model of state taxation on urban real estate on the basis of record management documents of the authorities of the Steppe and Turkestan Generalgovernorates, as well as statistical data. It is noted that the dominance of traditional economic relations in the Central Asian outskirts, the small presence in the regional economy of the market sector and the corresponding urban infrastructure precluded the possibility of carrying out here Zemstvo reform and the creation of local governments - Zemstvos. That fact defined features of formation of Zemstvo duties system, including the taxation on city real estate. They began to impose the tax in the Central Asian outskirts much later than in the whole Empire - in the late $19^{\text {th }}$ century, its distribution and control were entrusted to the regional and county governments. In the conditions of uneven growth of the number of cities and urban settlements in the Steppe Region and Turkestan in the post-reform period, the introduction of the urban real estate tax occurred in stages. Thus, in the Steppe Region the urban population began to pay the tax since the introduction of the Steppe situation in 1891(the introduction of the Steppe legal status in 1891), in Turkestan only since 1905 . In general, it should be noted that the amounts received from the collection of real estate tax were insignificant and could not fully financially ensure the infrastructural and social development of cities and urban settlements of the Central Asian outskirts of the Russian Empire.

^Работа выполнена за счет средств РНФ (проект № 19-18-00180). 
Ключевые слова: модернизация, Российская империя, Степной край, Туркестан, налоги, недвижимое имущество.

\section{DOI 10.14258/izvasu(2019)5-07}

Как известно, во второй половине XIX в. политической элитой Российской империи была инициирована серия буржуазных реформ, направленных на модернизацию страны и формирование новой политико-экономической системы, приближенной к европейским стандартам. Одним из ключевых моментов данных преобразований стала земская реформа 1864 г., предоставившая регионам возможность самоуправления. На основании Положения о губернских и уездных земских учреждениях формировались губернские и уездные земские собрания и земские управы, деятельность которых была направлена на социально-экономическое развитие административных единиц, в пределах которых они функционировали. Источником для развития транспортной системы, строительства и содержания социальных объектов, найма учителей, врачей, фельдшеров, «попечения» о развитии местной торговли и промышленности выступали натуральные и денежные земские повинности, в том числе налог на городское недвижимое имущество [1, с. 211-230].

Проведение буржуазных реформ в Российской империи во второй половине XIX в. совпало по времени с началом реализации политики интеграции центральноазиатских окраин в общеимперское политико-правовое и социально-экономическое пространство. Однако в условиях господства традиционных отношений в Степном крае и Туркестане, отсутствия в экономической структуре региона рыночного сектора и соответствующей ему городской инфраструктуры, незначительного количества городского населения проведение здесь земской реформы и создание органов местного самоуправления - земских собраний и управ - оказалось невозможным. В уездных городах Степного края общественное самоуправление в полном объеме было введено лишь в Петропавловске и Акмолинске. Численность гласных в городской думе Петропавловска, например, составляла 39 человек, а городская управа состояла из трех членов. В других городских поселениях региона (Кокчетаве, Атбасаре, Павлодаре, Каркаралинске, УстьКаменогорске и Зайсане) общественное самоуправление было введено в упрощенном виде - городская дума замещалась собранием уполномоченных в количестве от 12 до 15 человек, избираемых сходом домохозяев. Городской голова и городская управа заменялись в данном случае городским старостой с одним или двумя помощниками $[2, \pi .2]$.
Key word: modernization, Russian Empire, Steppe Region, Turkestan, taxes, real estate.

Данные обстоятельства определили особенности формирования системы земских повинностей, в том числе налогообложения на городское недвижимое имущество.

В отечественной историографии достаточно детально разработаны вопросы формирования и генезиса системы местного самоуправления. Анализу финансового обеспечения деятельности органов местного самоуправления, развитию структурных форм и расширению их финансовой базы в России второй половины XIX - начала XX в. уделяли внимание В. Безобразов, Л.Н. Лыкова, И.В. Караваева, И.В. Архипкин, B.М. Пушкарева [3-7]. Административно-правовые и организационно-управленческие основы регламентации фискальной политики земств в контексте буржуазных преобразований второй половины XIX в. детально разрабатывались в трудах В.Н. Захарова, Ю.А. Петрова, М.К. Шацилло [8].

Вопросы формирования и эволюции системы земских налогов и повинностей в национальных окраинах Российской империи - Степном крае и Туркестане - в историографии остаются недостаточно освещенными. Как правило, исследователи уделяют внимание социально-экономическому развитию центральноазиатского этнорегиона с акцентом на эволюцию налоговой системы, применявшейся в отношении коренного (казахского, киргизского и др.) и пришлого (крестьяне-переселенцы) населения [9-12]. История государственного налога на недвижимое имущество как составной части земских повинностей до сих пор остается за рамками внимания исследователей. На основе документов делопроизводства органов власти Степного и Туркестанского генерал-губернаторств, а также статистических данных нами предпринята попытка восполнить существующий историографический пробел.

В Степном генерал-губернаторстве налог на недвижимое имущество был законодательно закреплен в 1891 г. в рамках введения Степного положения об управлении Акмолинской, Семипалатинской, Семиреченской, Уральской и Тургайской областями. Налог был включен в общий перечень обязательных денежных земских повинностей наряду с покибиточной податью для кочевого населения, оброчной податью с оседлого крестьянского населения, налогом на фабричные и заводские помещения, торговые и промысловые свидетельства, патенты и билеты на содержание торговых и промышленных заведений. 
Поскольку, как уже отмечалось выше, в регионе не была проведена земская реформа и не были введены органы местного самоуправления - земства, заведование делами по земским повинностям было возложено на областные правления. При рассмотрении дел о земских повинностях на заседания общего присутствия областных правлений дополнительно приглашались председатель областного суда, управляющий почтовой частью в области, член от казачьих войск и городской голова областного города. В уездах делопроизводство и счетоводство по земским повинностям передавалось в компетенцию уездных начальников. Областные правления и уездные начальники руководствовались в вопросах налогообложения правилами Устава о земских повинностях [13, с. 125].

Участие в заседаниях общего присутствия областных правлений представителей Уральского и Сибирского казачьих войск определялось тем, что среди населения городов Уральской, Семипалатинской и Акмолинской областей казачество численно преобладало. Поскольку казаки обязывались снаряжать себя для несения воинской службы за счет собственных средств, они освобождались от уплаты каких-либо денежных земских повинностей, в том числе от государственного налога на недвижимое имущество. Лица иных сословий, проживающие в пределах городов и городских поселений трех указанных областей, выплачивали государственный налог на недвижимое имущество не только в пользу областных правлений или городских управ, но и в пользу Уральского казачьего войска [14, с. 17-18].

Так, например, в Семипалатинской области в 1908 г. на содержание волостного и сельского правлений, социальных объектов и иного было собрано земских сборов, в том числе налога на недвижимое имущество, на сумму 292970,2 руб. Из них 152717,1 руб. было израсходовано казахскими аульными и волостными обществами, 17498,9 руб. - сельскими/крестьянскими, 123054,2 руб. - казачьими обществами $[15$, с. 71$]$.

Формирование системы налогообложения городского населения Туркестанского генерал-губернаторства прошло несколько этапов. Так, с момента его образования в 1867 г. и до 1870 г. туземное население городов в рамках сложившейся до прихода русских в регион традиции было приравнено к категории сельских жителей и платило в пользу российской казны хараджный и танатный сборы. В 1870 г. последовало первое преобразование налоговой системы генерал-губернаторства: распоряжением правительства хараджный и танатный сборы были заменены поземельным налогообложением как сельских, так и городских жителей.

Временным положением 1886 г. об управлении Туркестанским генерал-губернаторством ситуация, связанная с введением поземельного налогообложения городского населения, была закреплена законодательно. К городским поселениям, обязанным выплачивать го- сударственный налог с городского недвижимого имущества, были отнесены местопребывания областных и уездных администраций, а также города Старый Маргелан и Чусть Ферганской области, Ура-Тюбе и Пенджикент Самаркандской и Туркестан Сыр-Дарьинской областей. Всего, таким образом, налогообложению подлежало 20 городских поселений [16, л. 59].

В начале 90-х гг. ХІХ в. в связи с развитием инфраструктуры и ростом численности русского населения городов Туркестана, строительством ОренбургскоТашкентской железной дороги и оживлением экономического развития региона Министерством финансов был актуализирован вопрос о введении в крае общеимперского законодательства в сфере налогообложения городского населения. В 1902 г. министерство представило на обсуждение законопроект о распространении на городские поселения коренных областей Туркестанского края Положения о налогах с недвижимого имущества в городах, поселениях и местностях. Проект предполагал разделение всего недвижимого имущества на собственно усадебные части и «части, лежащие вне усадебной черты». Его обсуждение состоялось в Петербурге в 1903 г. на созванном совещании с участием податных инспекторов областей Туркестанского генерал-губернаторства [16, л. 61].

По итогам работы совещания предложенный Министерством финансов вариант разделения недвижимого имущества на две категории был отклонен и принято решение о целесообразности «обложения всех находящихся в черте города имуществ на общеустановленных для империи основаниях, с теми только отступлениями, какие вызываются местными особенностями». В итоге в 1905 г. был утвержден законопроект, отменивший поземельный сбор с туземного населения городов Туркестана и вводивший государственный налог с недвижимого имущества для туземного и русского городского населения.

Система определения сумм налога осуществлялась в рамках общеимперского законодательства на основании ст. 85 Устава о прямых налогах, утвержденного в новой редакции в 1903 г. Согласно Уставу, она определялась на каждую область Туркестана ежегодно, распределялась между городскими поселениями областей, внутри них, а затем между отдельными окладными единицами. Размер земского обложения городских недвижимостей определялся ст. 320 Туркестанского положения, соответствующей ст. 407 Устава о земских повинностях [16, л. 61].

Поскольку в Туркестане, как и в Степном крае, земства и земское самоуправление не были введены, а городское самоуправление было введено только в Ташкенте, система налогообложения здесь приобрела некоторые специфические черты.

Во-первых, по аналогии со Степным краем назначение сумм налога на недвижимое имущество в условиях отсутствия земств было передано в функ- 
ционал областных правлений с участием в данном процессе в Сыр-Дарьинской области управляющего Туркестанской казенной палатой, в Семиреченской и Ферганской областях - с участием податных инспекторов областных городов. Утверждалась смета распределения налога на недвижимое городское имущество туркестанским генерал-губернатором.

Во-вторых, в городах распределение сумм налога между отдельными податными единицами осуществлялось вариативно. Так, в Казалинске и Перовске - особыми раскладочными по налогу с недвижимых имуществ присутствиями, в остальных городах - местными уездными поземельноподатными присутствиями.

В-третьих, для расклада сумм сборов внутри городов определялась действительная стоимость недвижимых имуществ, причем для русской части городов назначались особые части оклада налога, в туземной части - несколько общих окладов в соответствии с делением каждого туземного населения на части, так называемые аксакальства.

В-четвертых, в пределах каждого аксакальства распределение сумм налога между отельным недвижимым имуществом туземным населением осуществлялось в присутствии аксакала и выборных от владельцев имуществ, с применением ко всем плательщикам одинаковых правил налогообложения.

B-пятых, рассмотрение жалоб налогоплательщиков осуществлялось в уездных поземельно-податных комиссиях и областных правлениях Туркестанского генерал-губернаторства [16, л. 62].

В процессе внедрения в практику сбора государственного налога и недвижимого городского имущества региональные власти Степного края и Туркестана столкнулись с рядом проблем. Прежде всего, они были связаны с отсутствием в распоряжении большинства структур, осуществлявших раскладки сумм налогов, точных и приемлемых данных о численности недвижимого имущества в городах края и его стоимости. Для решения проблемы областными правлениями и уездно-податными комиссиями составлялись специальные схемы-матрицы оценки недвижимости, но даже они не могли полностью выправить ситуацию. Поэтому для восстановления полной картины стоимости недвижимости им приходилось подключать данные о страховых и за- логовых оценках и стоимости имущества по актам последнего приобретения [16, л. 62об.].

Данная ситуация влекла за собой задержку своевременного и правильного расклада государственного налога на недвижимое имущество в городах Степного края и Туркестана. Ситуация усугублялась отсутствием в некоторых областных правлениях и в городской управе Ташкента профессионально подготовленных кадров податных инспекторов. В результате нарушались все сроки, установленные для утверждения сметы налогов, рассылки окладных листов и взноса налога. Последний часто переносился на следующий календарный год. Так, например, окладные листы за 1905 г. были разосланы налогоплательщикам Туркестана только в начале 1906 г., а в некоторых уездных городах и в более поздние сроки, фактически одновременно с окладными листами за 1906 г. [16, л. 63].

Даже несколько лет спустя после введения в действие закона 1905 г. у региональных органов власти не имелось четкого представления о числе недвижимого имущества в Туркестанском генерал-губернаторстве. Его количество было определено приблизительно в 133728 единиц. Общая сумма налога на недвижимость городского населения трех областей Туркестанского генерал-губернаторства определялась государством в 140 тыс. руб. Из последних двух сумм следовало, что средняя норма государственного налога, приходящегося на каждое имущество, определялась приблизительно в 1,05 руб., а вместе с земским сбором - 1,4 руб.

Общая стоимость всей недвижимости, располагавшейся в городах Туркестана, оценивалась в 70000000 руб., средняя стоимость одной недвижимости - в 523 руб. Столь незначительные показатели объяснялись тем фактом, что большая часть недвижимого имущества приходилась на туземные части городов и не имела высокой ценности. В русской части городов края, особенно в Ташкенте и Самарканде, недвижимость оценивалась гораздо выше, и потому налог здесь, например в 1908 г., в среднем составлял 10,85 руб. на одно имущество, а средняя стоимость одного имущества оценивалась в 6050 руб. [16, л. 64].

Распределение сумм государственного налога на городское недвижимое имущество в городах Туркестанского края за 1908 г. можно представить по данным таблицы [16, л. 67об.].

Распределение сумм государственного налога

на городское недвижимое имущество в городах Туркестанского края, руб.

\begin{tabular}{|l|c|c|}
\hline \multicolumn{1}{|c|}{ Область } & $\begin{array}{c}\text { Назначенная на 1908 г. сумма } \\
\text { государственного налога на городское } \\
\text { недвижимое имуществ }\end{array}$ & $\begin{array}{c}\text { Сумма недоимок на начало 1909 г. } \\
\text { по сбору государственного налога } \\
\text { на городское недвижимое имущество }\end{array}$ \\
\hline Сыр-Дарьинская & 61500 & 41544,2 \\
\hline Самаркандская & 25500 & 19283,9 \\
\hline Ферганская & 53000 & 30108 \\
\hline Итого & 140000 & 90936,1 \\
\hline
\end{tabular}


Данные таблицы свидетельствуют о том, что с момента введения денежного налогообложения в Туркестанском крае на городское недвижимое имущество с 1905 г. остро стояла проблема недоимок. В 1908 г. региональные областные бюджеты недополучили 90936,1 руб. (около 65\%) данного налога. Такая ситуация являлась характерной и для областей Степного края. Например, в Семипалатинской области в 1898 г. должно было быть собрано налога с недвижимого имущества 9479,14 руб., реально поступило 9245, 48 руб. Таким образом, недоимки составили 233,69 руб. [17, с. 46]

В заключение следует отметить, что в рамках общеимперского законодательства собранные суммы от государственного налога на городское недвижимое имущество Степного края и Туркестана вместе с остальными денежными земскими налогами направлялись на формирование городских бюджетов. Однако во второй половине XIX в. отставание в темпах экономического развития региона создавало в данном направлении определенные трудности. Только в начале XX в., по мере роста торгово-промышленного значения некоторых уездных городов Степного края и Туркестана, доходная часть их бюджетов увеличилась. Например, доходы городской казны в Петропавловске с 1898 по 1909 г. увеличились с 60 тыс. до 215 тыс. руб., в Акмолинске, соответственно, - с 27812 руб. до 75 тыс. руб., в Кокчетаве - с 1898 по 1909 г. возросли с 2649 руб. до 11168 руб. [18, с. 18].

В связи с ростом доходной части бюджетов в начале XX в. городские самоуправления в Степном крае стали выделять больше средств на развитие городского хозяйства и социально-культурную сферу. В Петропавловске, например, в 1901-1914 гг. по решению городской думы проводилось сооружение водопровода и его ответвлений к больнице, зданию переселенческого пункта, меновому двору, скотобойне, консервному заводу и частным домам. По инициативе городской управы Семипалатинска в 1887 г. в городе было открыто отделение Госбанка [19, л. 1].

Однако в целом возможности городских самоуправлений в других уездных поселениях Степного края в силу нехватки финансовых средств были весьма ограничены. Поэтому зачастую забота городских властей о благоустройстве вверенных им поселений сводилась лишь к принятию постановлений, содержащих требования к горожанам соблюдать элементарные санитарно-гигиенические нормы. Не случайно, как отмечает Р.М. Джаниева, «органы городского самоуправления добивались более широкой помощи со стороны государства в решении насущных вопросов развития городского хозяйства и социально-культурной сферы, настаивали на увеличении отчислений в городские бюджеты и т.д.» [20, с. 15].

Таким образом, на процесс формирования модели государственного налогообложения на недвижимое городское имущество в центральноазиатских окраинах Российской империи существенное влияние оказал ряд факторов. Среди них: господство традиционных экономических отношений, незначительное присутствие в региональной экономике рыночного сектора и соответствующей ему городской инфраструктуры, замедленные темпы урбанизации и т.д. В свою очередь данные факты исключали возможность проведения здесь земской реформы и создания органов местного самоуправления - земств. Поэтому налог на городское недвижимое имущество начали вводить в центральноазиатских окраинах гораздо позднее, чем в целом по империи в конце XIX в., его распределение и контроль были возложены на областные и уездные правления. В условиях неравномерного роста численности городов и городских поселений в областях Степного края и Туркестана в пореформенный период введение государственного налога на городское недвижимое имущество происходило поэтапно. Так, в Степном крае городское население стало выплачивать данный налог с момента введения Степного положения в 1891 г., в Туркестане - только с 1905 г. В целом, следует отметить, что суммы от сбора налога на недвижимое имущество были незначительными и не могли в полном объеме финансово обеспечить инфраструктурное и социальное развитие городов и городских поселений центральноазиатских окраин Российской империи.

\section{Библиографический список}

1. Земская реформа // Реформы Александра II / сост. и авт. предисл. О.И. Чистяков, Т.Е. Новицкая. М., 1998.

2. Центральный государственный архив Республики Казахстан. Ф. 369. Оп. 1. Д. 4783.

3. Безобразов В. Земские учреждения и самоуправление. М., 1974.
4. Государственные финансы России (XIX - первая четверть ХХ в.) / под ред. И.В. Караваевой. М., 2003.

5. Караваева И.В., Архипкин И.В. Местные финансы и местные налоги в России XIX-XX вв. М., 2005.

6. Лыкова Л.Н. Налоги и налогообложение в России. M., 2006. 
7. Пушкарева В.М. Исторический очерк развития финансовой науки. М., 2000.

8. Захаров В.Н., Петров Ю.А., Шацилло М.К. История налогов в России. IX - начало XX в. М., 2006.

9. Лысенко Ю.А. Вопрос о воинской повинности для казахского населения (70 гг. XIX - начало XX в.) // Известия Алт. ун-та. 2012. № 4-2.

10. Лысенко Ю.А. К вопросу о налоговой политике Российской империи в отношении казахского общества // Известия Алт. ун-та. 2013. № 4-2.

11. Масанов Н.Э. Налоговая политика царизма в Казахстане (20-60-е гг. XIX в.) : автореф. дис. ... канд. ист. наук. Алма-Ата, 1960.

12. Сапелкин А. Налоговая политика царизма в Киргизии (1867-1914) : автореф. дис. ... канд. ист. наук. Фрунзе, 1963.

13. Положение об управлении областей Акмолинской, Семипалатинской, Семиреченской, Уральской и Тургайской 1891 г. // Толочко А.П. Омск в истории русско-казах- ских экономических, культурных и общественных связей (конец XIX - начало XX вв.). Омск, 2010.

14. Обзор Уральской области за 1900 г. Уральск, 1901 г.

15. Обзор Семипалатинской области за 1908 г. Семипалатинск, 1909.

16. Российский государственный исторический архив (РГИА). Ф. 1396. Оп. 1. Д. 425.

17. Обзор Семипалатинской области за 1898 г. Семипалатинск, 1899.

18. Еремина Л. А. Городское самоуправление в Западной Сибири в конце XIX - начале XX веков: структура, функции, основные направления деятельности : автореф. дис. ... канд. ист. наук. Новосибирск, 2001.

19. РГИА. Ф 587. Оп. 30. Д. 520.

20. Джаниева Р. М. Социально-экономическое и культурное развитие уездных городов Степного края в конце XIX - начале XX вв. : автореф. дис. ... канд. ист. наук. Омск, 2017. 